\title{
Agriculture production as a major driver of the Earth system exceeding planetary boundaries
}

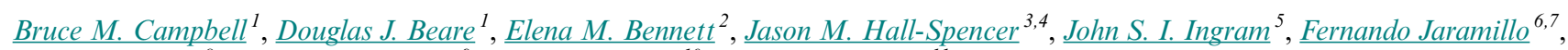 \\ $\underline{\text { Rodomiro Ortiz }}^{8}$, Navin Ramankutty $^{9}$, Jeffrey A. Saver $^{10}{\text { and }{ }^{\text {Drew Shindell }}}^{11}$
}

\begin{abstract}
We explore the role of agriculture in destabilizing the Earth system at the planetary scale, through examining nine planetary boundaries, or "safe limits": land-system change, freshwater use, biogeochemical flows, biosphere integrity, climate change, ocean acidification, stratospheric ozone depletion, atmospheric aerosol loading, and introduction of novel entities. Two planetary boundaries have been fully transgressed, i.e., are at high risk, biosphere integrity and biogeochemical flows, and agriculture has been the major driver of the transgression. Three are in a zone of uncertainty i.e., at increasing risk, with agriculture the major driver of two of those, landsystem change and freshwater use, and a significant contributor to the third, climate change. Agriculture is also a significant or major contributor to change for many of those planetary boundaries still in the safe zone. To reduce the role of agriculture in transgressing planetary boundaries, many interventions will be needed, including those in broader food systems.
\end{abstract}

Key Words: aerosol loading; biogeochemical flows; biosphere integrity; chemical pollution; climate change; diversity; freshwater; land-system change; nitrogen; ocean acidification; ozone depletion; phosphorous

\section{INTRODUCTION}

Some scholars suggest that the world has now entered the "Anthropocene" an era in which human activities significantly impact Earth system functioning (Crutzen and Stoermer 2000). The profound, and almost omnipresent, impact of agriculture on the environment is well documented (Foley et al. 2005, Beddington et al. 2012) and manifests itself via multiple interacting pathways, e.g., land-cover change, greenhouse gas emissions, excessive water use, and biodiversity impacts.

In 2009 Rockström et al. (2009a,b) introduced the concepts of "planetary boundaries" (PBs) and a "safe operating space for humanity," which have recently been revised by Steffen et al. (2015). The PBs are intended to represent Earth system processes, which, if crossed, could generate unacceptable environmental change potentially endangering human existence. The nine PBs currently recognized (Steffen et al. 2015) are the following:

1. Land-system change;

2. Freshwater use;

3. Biogeochemical flows - nitrogen and phosphorous cycles;

4. Biosphere integrity;

5. Climate change;

6. Ocean acidification;

7. Stratospheric ozone depletion;

8. Atmospheric aerosol loading; and

9. Introduction of novel entities.
There are many ways that agricultural production, essential for human survival, is pushing the Earth system, or regions within it, over one boundary or another. We examine the extent to which global agricultural production is responsible for shifting the Earth system toward, or over, the boundary of a safe operating space for humanity (Rockström et al. 2009a,b).

Quantification of PBs is the subject of ongoing research and debate. Steffen et al. (2015) suggest that at least four PBs have already been exceeded or are in a zone of uncertainty, i.e., high or increasing risk: climate change, land-system change, biogeochemical flows, and biosphere integrity. There is also considerable debate as to whether or not the freshwater use PB has been exceeded (Gerten et al. 2015). Although many of the numerical values set for PBs will be revised, we believe nonetheless that the concept provides a useful basis for assessing the effects of agriculture on the Earth system, and can be used to stimulate urgent transformation of the food and agriculture sector.

\section{LAND-SYSTEM CHANGE}

The link between land-system change and agriculture is clear and consistent. According to Foley et al. (2005), croplands and pastures are one of the largest terrestrial biomes on the planet, occupying $\sim 40 \%$ of land surface. This makes agricultural production the planet's single most extensive form of land use. In the tropics, new agricultural land has come at the expense of rainforests, savanna, and other ecosystems, and future expansion will clear ever more (Gibbs et al. 2010). There is also a feedback in which emissions of methane and nitrous oxide from agriculture lead to crop yield reductions, so that agricultural expansion can require further expansion (Shindell 2016).

${ }^{1}$ CGIAR Research Program on Climate Change, Agriculture, and Food Security (CCAFS), International Center for Tropical Agriculture (CIAT), c/o University of Copenhagen, ${ }^{2} \mathrm{McGill}$ School of Environment and Department of Natural Resource Sciences, McGill University, ${ }^{3}$ Marine Biology and Ecology Research Centre, University of Plymouth, UK, ${ }^{4}$ Shimoda Marine Research Centre, University of Tsukuba, Japan, ${ }^{5}$ Food Systems Research Programme, Environmental Change Institute, The University of Oxford, UK, ${ }^{6}$ Stockholm Resilience Center, Stockholm University, Sweden, ${ }^{7}$ Department of Physical Geography and Bolin Centre for Climate Research, Stockholm University, Sweden., ${ }^{8}$ Department of Plant Breeding, Swedish University of Agricultural Sciences, Sweden, ${ }^{9}$ UBC School of Public Policy and Global Affairs and Institute for Resources, Environment, and Sustainability, University of British Columbia, ${ }^{10}$ Centre for Tropical Environmental and Sustainability Science, College of Marine \& Environmental Sciences, James Cook University, Cairns, Australia, ${ }^{11}$ Nicholas School of the Environment, Duke University, Durham, NC, USA 
Bioenergy with carbon capture and storage (BECCS) is increasingly suggested as a key component for meeting climate targets. But this has the potential of increasing competition with food production and inducing large-scale land-use changes. Thus recent studies suggest that BECCS may only be feasible on more modest scales as a "supporting actor" for strong mitigation actions (Boysen et al. 2017, Smith et al. 2016). Even with substantial yield increases and intensification, if humanity is to meet future demand for food and biofuels, net area under agriculture will have to expand, putting further pressure on important biomes.

Rockström et al. (2009a) suggested that no more than 15\% of the Earth's ice-free surface should be converted to cropland. Steffen et al. (2015) changed the control variable from the amount of cropland to the amount of forest cover remaining, because the major forest biomes play a stronger role in land surface-climate coupling than other biomes. They set the boundary at $75 \%$ (a weighted average of the boundaries for tropical, temperate, and boreal forests) with a zone of uncertainty at $54-75 \%$ (forest remaining as a percentage of original area), and they calculate the current value as $62 \%$.

In 2000 , there were $\sim 15$ million $\mathrm{km}^{2}$ of cropland and 28 million $\mathrm{km}^{2}$ of pasture on Earth corresponding to $\sim 12 \%$ and $28 \%$ of its ice-free land surface, respectively (Ramankutty et al. 2008). Past trends imply that $\sim 10$ million $\mathrm{km}^{2}$ of land will be cleared by 2050 to meet demand. This will bring another $\sim 8 \%$ of the Earth's icefree land surface under agriculture, crossing the PB set by Rockström et al. (2009a).

We have followed the Steffen et al. (2015) framing of the boundary. Although agriculture has undoubtedly contributed substantially to forest loss, it is no simple matter to calculate the exact contribution. The expansion of land under agriculture has caused a net loss of $\sim 7$ to 11 million $\mathrm{km}^{2}$ of forest in the past 300 years (Foley et al. 2005). Between 1980 and 2000, more than 55\% of new land for agriculture replaced pristine forests, while $28 \%$ came from degraded forests (Gibbs et al. 2010). On a global scale, roughly $30 \%$ of temperate deciduous forests have been converted to cropland. On a positive note, forest gain is now occurring at higher latitudes and in richer countries, though loss continues in poor countries in the tropics (Sloan and Sayer 2015). One of the few studies to estimate the role of different factors in forest loss is that of Blaser and Robledo (2007). Using their figures it is estimated that agriculture has caused $75 \%$ of deforestation in areas experiencing deforestation in the period 1990-2005. Kissinger et al. (2012) and Hosonuma et al. (2012), using FAO data, estimate that agriculture is the driver for around $80 \%$ of deforestation worldwide in the period 2000-2010. We thus use $80 \%$ in Figure 1.

Rockström et al. (2009a) recommend implementation at multiple scales, including reserving space most suited to agriculture, maintaining high conservation-value forests, and keeping carbonrich soils and ecosystems in either a totally undisturbed or at least carefully managed condition. Sustainable intensification of agriculture to limit the area under cultivation is crucial.
Fig. 1. The status of the nine planetary boundaries (PBs; green, yellow, red) overlaid with our estimate of agriculture's role in that status. PBs based on Steffen et al. (2015), with modification for freshwater from below boundary (safe) into a zone of uncertainty (Gerten et al. 2013, Jaramillo and Destouni $2015 a$ ), and an estimate for functional diversity based on Newbold et al. (2016).

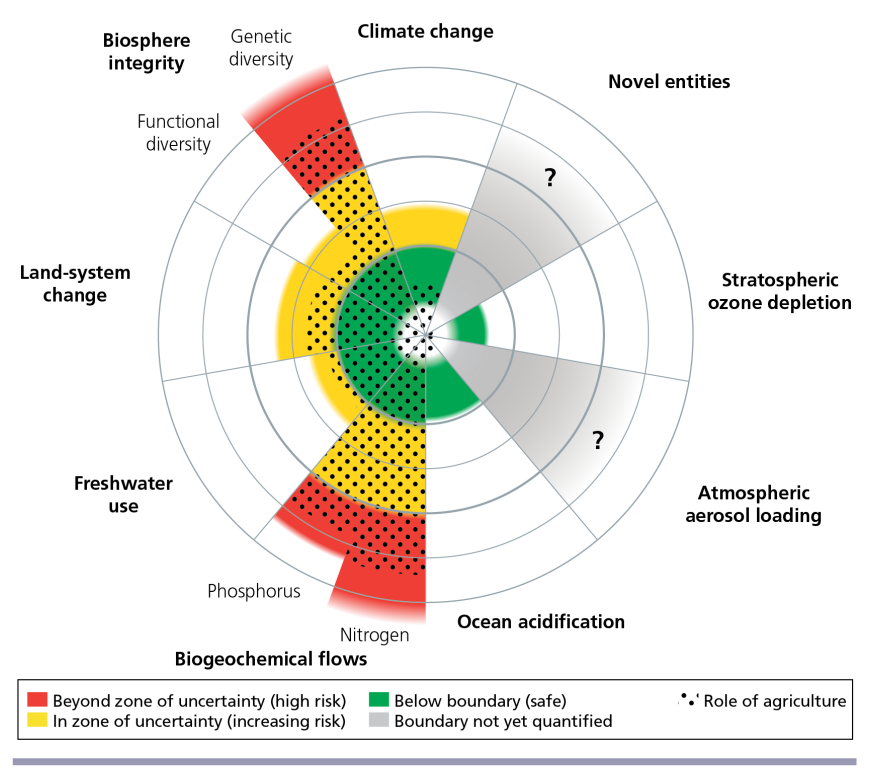

\section{FRESHWATER USE}

Of all human activities, agriculture, and specifically crop production, consumes the largest amount of water, mainly via transpiration from crop plants and evaporation from soils and irrigation structures. Agriculture accounts for $\sim 70 \%$ of global freshwater withdrawals. The amount varies regionally: $44 \%$ of total water withdrawal in OECD countries, $\sim 87 \%$ in African countries, $\sim 80 \%$ in Asia, and more than $90 \%$ in some Arab countries (World Water Assessment Programme 2012a,b,c). A distinction can be made between "blue water" consumption (withdrawal of water from rivers, reservoirs, lakes, and aquifers) and "green water" consumption (the direct use of rainwater).

In order to determine the "safe space" for humanity in relation to freshwater use, Rockström et al. (2009a) originally suggested a freshwater PB of $4000 \mathrm{~km}^{3} \mathrm{yr}^{-1}$ with a zone of uncertainty of $4000-6000 \mathrm{~km}^{3} \mathrm{yr}^{-1}$, and global consumptive use of blue water to be used as a control variable for its monitoring. The monitoring and quantification of the freshwater PB is becoming increasingly contentious. Although it was suggested that the original PB should be compared against consumptive blue water use, Jaramillo and Destouni (2015a) state that because of the complementarity of blue and green water suggested by Rockström et al. (2009a), total consumption from blue and green water should be used to monitor the PB of freshwater instead of only blue water. From this perspective, the increase in human global consumption of freshwater during the 20th century and 
beginning of the 21st century may have already transgressed the PB of $4000 \mathrm{~km}^{3} \mathrm{yr}^{-1}$ (Destouni et al. 2013, Jaramillo and Destouni $2015 a, b$,$) .$

Besides these latter hydroclimatic observation-based studies, others have used global hydrological modeling to estimate human water consumption. For instance, Siebert and Döll (2010) used a crop model to estimate that rain fed crops consume $4586 \mathrm{~km}^{3} \mathrm{yr}^{-1}$ of green water worldwide, and irrigated crops $2099 \mathrm{~km}^{3} \mathrm{yr}^{-1}$ (1180 $\mathrm{km}^{3} \mathrm{yr}^{-1}$ of blue water and around $919 \mathrm{~km}^{3} \mathrm{yr}^{-1}$ of green water). There is, however, still no real consensus on the amount of blue and green water that is consumed by agriculture.

Molden (2009:117) argues that the water boundary suggested by Rockström et al. (2009a) may be too high because "the concept of a global limit overlooks the importance of local conditions and the role of management in magnifying or ameliorating problems." For this reason, Steffen et al. (2015) introduced subglobal freshwater boundaries that are specific to each basin in order to monitor the sustainability of freshwater consumption at more local and regional scales. A further re-evaluation of the freshwater PB by Gerten et al. (2013) has reduced the global freshwater $\mathrm{PB}$ value to $2800 \mathrm{~km}^{3} \mathrm{yr}^{-1}$, with corresponding uncertainty range of $1100-4500 \mathrm{~km}^{3} \mathrm{yr}^{-1}$, meaning that the current status of freshwater use is already in the zone of uncertainty (increasing risk).

For simplicity, we follow Steffen et al. (2015) in their setting of the global freshwater planetary boundary at $4000 \mathrm{~km}^{3} / \mathrm{yr}$ and their use of blue water consumption as the control variable, but modify the boundary, following Gerten et al. (2013) and Jaramillo and Destouni $(2015 b)$. We put agriculture's role in the status of this $\mathrm{PB}$ at the $84 \%$ level (Fig. 1), following Shiklomanov and Rodda (2003) who estimated that blue water consumption by irrigated agriculture makes up $84 \%$ of all human blue water consumption.

The amount of water needed to produce food depends on what is being cultured and the production method. With a growing human population and a shift in dietary preferences toward more meat, ever more water will be required. The growth in livestock production, in particular, increases water consumption owing to the extra demand for water to grow crops used to feed livestock. Increased biofuel production will further increase pressures on water resources. Additionally, according to Jaramillo and Destouni (2015b), many dams constructed worldwide to impound and store water for crop irrigation may be consuming considerable amounts of blue and green water that have been currently disregarded in crop model estimates.

Agriculture is, and will continue to be, the largest consumer of freshwater globally. In addition to the absolute amount, ground water depletion in some regions is also a major concern with levels dropping by over $300 \mathrm{~mm} \mathrm{yr}^{-1}$ in the Indo-Gangetic Plain (Wada et al. 2010). It should then be a priority to reduce the level of uncertainty of freshwater consumption from agriculture and related human activities in order to estimate forthcoming water scarcity and its management (Jaramillo and Destouni 2015b). Although water availability is projected to decrease in many regions, "future global agricultural water consumption alone (including both rainfed and irrigated agriculture) is estimated to increase by about $19 \%$ by 2050 " (World Water Assessment Programme 2012a,b,c:269). Although the quantity of water used per unit of food produced has almost halved since 1961 (World Water Assessment Programme 2012a), the potential to increase water-use efficiency in agriculture remains substantial. Water management, policy reforms, and infrastructure investments can all contribute to increasing efficiency and lowering consumption. Water use for irrigation can be lowered by increasing conveyance efficiency (taking water from the source to the farm), distribution efficiency (farm to field), and application efficiency (application to crops; Rosegrant et al. 2009).

\section{BIOGEOCHEMICAL FLOWS}

Although Steffen et al. (2015) suggest that PBs need to be calculated for multiple elements, we follow their pragmatic approach of limiting the analysis to nitrogen $(\mathrm{N})$ and phosphorus $(\mathrm{P})$. Nitrogen $(\mathrm{N})$ is an essential macronutrient and the limiting element for plant growth in many terrestrial and aquatic ecosystems. Human activities have profoundly transformed the global N cycle (Swaney et al. 2012), with the main drivers being the increased use of fossil fuels, agriculture, and industry's growing demand for $\mathrm{N}$, and low use-efficiencies. Anthropogenic $\mathrm{N}$ sources now contribute more $\mathrm{N}$ to the Earth system than all natural terrestrial processes combined (Rockström et al. 2009a, Canfield et al. 2010). The excessive amount of $\mathrm{N}$ leads to soil and air pollution, drives biodiversity loss, pollutes coastal marine waters and watersheds (Howarth et al. 2011, Swaney et al. 2012), and increases the level of $\mathrm{N}_{2} \mathrm{O}$ and reactive $\mathrm{N}$ gases in the troposphere (Robertson and Vitousek 2009, Canfield et al. 2010, Bodirsky et al. 2012). The environmental costs of $\mathrm{N}$ losses in Europe have been estimated to outweigh the entire direct economic benefits of $\mathrm{N}$ in agriculture combined (Sutton et al. 2011).

The Steffen et al. (2015) global boundary for $\mathrm{N}$ is taken from the analysis of de Vries et al. (2013), which proposed a PB of $62 \mathrm{Tg}$ $\mathrm{N} \mathrm{yr}^{-1}$ from industrial and intentional biological $\mathrm{N}$ fixation, set to avert eutrophication of aquatic ecosystems. Steffen et al. (2015) introduce regional boundaries for $\mathrm{N}$, and it is specific regions where transgression has occurred, particularly North America, Europe, South Asia, and China.

Large amounts of $\mathrm{N}$ required for plant and livestock production results in agricultural activities being the main driver of the $\mathrm{N}$ cycle (Galloway et al. 2008, Liu et al. 2010, Bodirsky et al. 2012). According to Fixen and West (2002) the use of N fertilizer in agriculture increased by approximately $800 \%$ from 1960 to 2000 although estimates vary. Liu et al. (2010), for example, found total $\mathrm{N}$ input to croplands in 2000 to be about $137 \mathrm{Mt} \mathrm{N} \mathrm{yr}^{-1}$, whereas Bouwman et al. (2009) estimated total agricultural N input at 249 Mt $\mathrm{N} \mathrm{yr}{ }^{-1}$. Agricultures' share of total global anthropogenic $\mathrm{N}$ use (187 $\mathrm{Mt} \mathrm{N} \mathrm{yr}^{-1}$ ) has been estimated at $86.1 \%$ (Galloway et al. 2008), and so we use $\sim 85 \%$ as the level in Figure 1.

Several studies also reveal low $\mathrm{N}$ use efficiency in crops; only approximately half of the $\mathrm{N}$ applied to croplands is incorporated into plant biomass, while the remains are lost through leaching $(16 \%)$, soil erosion (15\%), and gaseous emission (14\%; Liu et al. 2010, Bodirsky et al.2012). According to Robertson and Vitousek (2009) crop rotation, improved prediction of crop fertilizer $\mathrm{N}$ requirements, timing and placement, along with strategies to recoup $\mathrm{N}$ losses, are all currently available practices that can substantially reduce $\mathrm{N}$ loss. 
Most agricultural production is dependent on $\mathrm{P}$ in the form of phosphate $\left(\mathrm{PO}_{4}{ }^{3-}\right)$ from fertilizers or manures, which improve soil and replenish what is removed when crops are harvested (Cordell and White 2013). Human activities have profoundly changed the global $\mathrm{P}$ cycle, primarily through mining rock phosphate to produce $\mathrm{P}$ fertilizers for agricultural uses. The $\mathrm{P}$ cycle is accelerated two to three times over background rates (Smil 2000), leading to eutrophication of freshwater and estuarine systems (Diaz and Rosenberg 2008) in addition to the intended increase in agricultural production.

Steffen et al. (2015) also propose a two-level approach for the P component of the biogeochemical flows boundary, based on the analysis of Carpenter and Bennett (2011). The global boundary is set at $11 \mathrm{Tg} \mathrm{P} \mathrm{yr}^{-1}$ from freshwater systems into the ocean to avoid large-scale ocean anoxic events, which potentially explain past mass extinctions of marine life (Handoh and Lenton 2003). Regional boundaries are set to prevent eutrophication of freshwater, and as for the $\mathrm{N}$ component, it is particular regions where these boundaries are transgressed.

Smil (2000) indicates that $90 \%$ of global phosphate production (around $148 \mathrm{Mt}$ of phosphate rock per year) is used to make fertilizers for agriculture. More recent research suggests that as much as $96 \%$ of mined $\mathrm{P}$ is used for fertilizer production (22.6 $\mathrm{Mt} \mathrm{yr}^{-1}$ out of a total anthropogenic production of $23.5 \mathrm{Mt} \mathrm{yr}^{-1}$ ), and nearly all of this $\mathrm{P}$ is added to terrestrial soil (Carpenter and Bennett 2011). With increased global demand for food due to rising population numbers and changing diets, demand for $\mathrm{P}$ could increase by $50-100 \%$ by 2050 (Cordell and White 2013), leading to even greater impact of agriculture on this already surpassed boundary. We estimate agriculture's role in the PB as being greater than $90 \%$ (Fig. 1).

Several options exist to reduce agricultures' contribution to the current transgression of this PB (Elser and Bennett 2011, Cordell and White 2013). The most systemic options revolve around using less new P. For this, one option is to balance $\mathrm{P}$ budgets on agricultural soils and another is to increase use of recycled $P$ from manure, human excreta, and food residues to reduce reliance on new, mined P. A somewhat less systemic, but still important solution is to reduce $\mathrm{P}$ losses from farms to aquatic systems. This type of P runoff could be minimized through: (i) using better tillage practices; (ii) establishing and maintaining riparian buffers; or (iii) restoring wetland areas. Finally, reducing food waste, in storage or in after-market waste, so that less has to be produced in the first place is an urgent consideration.

\section{CHANGE IN BIOSPHERE INTEGRITY}

In their original paper Rockström et al. (2009a) included "rate of biodiversity loss" as one of the nine PBs but this was altered by Steffen et al. (2015) to "change in biosphere integrity" with the intention of better reflecting the more general impact of human activities on the biosphere by encompassing both genetic and functional diversity. The authors suggest that genetic diversity can be measured by extinction rates and functional diversity by the biodiversity intactness index (BII).

Steffen et al. (2015) retain the average number of extinctions per million species-years (E/MSY) as a proxy for measuring genetic diversity loss, although it is criticized for being difficult to measure and inevitably has a time-lag. Recent estimates suggest that there are likely to be $\sim 5 \pm 3$ million species on Earth and some current models predict extinction rates of less than $5 \%$ per decade, although the impact of climate change on extinctions is particularly uncertain (Costello et al. 2013). Although 5\% per decade does not sound catastrophic, Steffen et al. (2015) suggest an "aspirational" $\mathrm{PB}$ of $1 \mathrm{E} / \mathrm{MSY}$ and a more realistic one of 10 E/MSY. As a point of reference, past average extinction rates for marine organisms in the fossil record are comparatively well known, and estimated to be in the order of 0.1 to $1 \mathrm{E} / \mathrm{MSY}$. The current rate, however, is thought to be in excess of $100 \mathrm{E} / \mathrm{MSY}$, with future projections of loss in the order of 1000-10,000 E/ MSY.

Functional diversity describes the overall role of the biosphere in Earth system functioning. A BII of $90 \%$ was suggested as a PB by Steffen et al. (2015) with a large interval of uncertainty (90$30 \%$ ). Newbold et al. (2016) estimate that land use and related pressures have already reduced local biodiversity intactness beyond the PB across $58 \%$ of the world's land surface. The BII is probably in the zone of uncertainty, and this is where we place it on Fig. 1.

In the absence of better information, we suggest $80 \%$ as the role of agriculture in the status of the biosphere integrity PB (Fig. 1), i.e., the same value as that for land-system change given that losses of both genetic and functional diversity loss are driven by landsystem change. Thus agriculture has shifted biosphere integrity beyond the PB, at least for one of the components of this PB. Biodiversity loss is not only a function of habitat area, and biosphere integrity may have more to do with functional diversity than genetic diversity (Steffen et al. 2015). The world's forests are rapidly being fragmented by a huge expansion of investments in infrastructure, with agriculture a key constituent of the new landscapes (Sloan and Sayer 2015). Development corridors are seen as a way of transforming agriculture in developing countries to higher levels of productivity. These development corridors risk major fragmentation and occupation of existing forests, especially in the tropics, with potentially disastrous consequences for biosphere integrity (Laurance et al. 2015). Climate change and habitat fragmentation are facilitating the spread of exotic invasive species into natural habitats at an unprecedented level with alarming consequences for biodiversity and ecosystem function.

\section{CLIMATE CHANGE}

Agricultural activities emit large amounts of important non- $\mathrm{CO}_{2}$ greenhouse gases, while deforestation, to create more space for agriculture, releases significant amounts of $\mathrm{CO}_{2}$. The entire food chain and its related activities, from production of fertilizer to distribution of food commodities, also emit significant amounts of $\mathrm{CO}_{2}$. All combined, this places agriculture as one of the most important anthropogenic activities contributing to climate change. Furthermore, climate change will itself influence the conditions for agriculture and will have significant ramifications for the entire agricultural system.

Rockström et al. (2009a) proposed a dual approach for climate change using both atmospheric $\mathrm{CO}_{2}$ concentration and top-ofatmosphere radiative forcing as global scale control variables, suggesting $350 \mathrm{ppm} \mathrm{CO}_{2}$ and $1 \mathrm{~W} \mathrm{~m}^{-2}$ above preindustrial level as the two boundaries (US EPA 2011). This was based on (i) an analysis of the equilibrium sensitivity of the climate system to greenhouse gas forcing; (ii) the behavior of the large polar ice 
sheets under climates warmer than those of the Holocene; and (iii) the observed behavior of the climate system at a current $\mathrm{CO}_{2}$ concentration of about $387 \mathrm{ppm}$ and $+1.6 \mathrm{~W} \mathrm{~m}^{-2}(+0.8 /-1.0 \mathrm{~W}$ $\mathrm{m}-2)$ net radiative forcing. Rockström et al. (2009a) noted that climate sensitivity to so-called "slow feedback," e.g., decreased ice sheet volume, and disappearance of the cooling effect of aerosols must be taken into account when setting the boundary. There is another important interaction between the aerosol PB and the climate change PB (Mahowald et al. 2017). It is estimated that increases in nutrient subsidies from atmospheric deposition are causing an increase in carbon dioxide uptake. As aerosol emissions from industrial sources are reduced to improve air quality, these enhancements in carbon uptake may be reduced.

Agriculture contributes $\sim 5.0$ to $5.8 \mathrm{Gt} \mathrm{CO}_{2} \mathrm{e} \mathrm{yr}^{-1}$, based on the 100 -year global warming potential, or $\sim 11 \%$ of total anthropogenic greenhouse gas emissions, not including agriculturally driven land use change (Smith et al. 2014). Developing countries collectively produce the majority of agriculture-related emissions globally and are where emissions are expected to rise the fastest, given the potentials to increase agricultural production in developing countries (Smith et al. 2014). Agricultural emissions are also significant at national levels, contributing an average of $35 \%$ of emissions in developing countries and $12 \%$ in developed countries (Richards et al. 2015). The inclusion of emissions from the entire food system, from production to consumption, increases the contribution from 14 $24 \%$ (with agriculturally driven land use change included) to 19$29 \%$ of total greenhouse gas emissions (Vermeulen et al. 2012). This figure includes the entire supply chain, fertilizer manufacture, agricultural production itself, processing, transport, retail, household food management, and waste disposal. We have used $25 \%$ as the role of agriculture (inclusive of agriculturally driven land cover change) in the status of this PB (Fig. 1).

Wollenberg et al. (2016) estimate that agriculture must reduce its

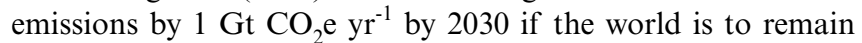
within the $2{ }^{\circ} \mathrm{C}$ target, while at the same time feeding a growing and more affluent human population. Using two different approaches and with prices of up to US\$20 per $\mathrm{t} \mathrm{CO}_{2} \mathrm{e}$, they estimate that only 21 to $40 \%$ of the needed mitigation can be achieved; this includes widespread use of technical agronomic practices and intensified production of crops and livestock with increases in efficiency. The large gap between desired mitigation outcomes and plausible outcomes indicates that more transformative technical and policy options will be needed, for example high-tech solutions such as livestock breeds that produce less methane and greater retention of soil organic matter in soils. At the same time, reducing land use change due to clearing for agriculture, decreasing food loss and waste, and shifting dietary patterns will also be required.

\section{OCEAN ACIDIFICATION}

Ocean acidification is caused by carbon dioxide emissions to the atmosphere, about $25 \%$ of which have been absorbed into seawater where it forms carbonic acid. This has already caused a $34 \%$ increase in seawater acidity since 1800 , and unless we reduce $\mathrm{CO}_{2}$ emissions this will cause about a $150 \%$ increase in surface ocean acidity by 2100 (Hönisch et al. 2012). This is the fastest rate of chemical ocean change for millions of years.
Many marine taxa, e.g., corals and oysters, use aragonite or calcite to build protective shells or skeletons that are easily corroded when seawater $\mathrm{CO}_{2}$ levels build up (Rodolfo-Metalpa et al. 2011). Coral reefs are made out of aragonite and when the "aragonite saturation state" ( $\Omega$ arag) is below 1 then the reefs dissolve. Coral reefs form in waters that are supersaturated with aragonite $(\Omega$ arag $>3$ ), below this the reefs are weaker and easily eroded by borers, e.g., algae and sponges, and grazers, e.g., sea urchins and parrotfish.

Rockström et al. (2009b) proposed an ocean acidification boundary where, "oceanic aragonite saturation state is maintained at $80 \%$ or higher of the average global pre-industrial surface seawater $\Omega$ arag of 3.44." Currently, $\Omega$ arag is $\sim 84 \%$ of the preindustrial value and falling rapidly (Gattuso et al. 2015).

The agriculture sector directly contributes to ocean acidification because it is a major source of $\mathrm{CO}_{2}$ emissions. There are also indirect effects, for example through acidification of water catchment areas on arable land, as well as via nutrient input from fertilizers to the seas and oceans. Production of reactive nitrogen for fertilizers for agriculture is one of the hall-marks of the Anthropocene; nitrate inputs to coastal waters stimulate algal growth, which lowers dissolved oxygen levels as it rots. The $\mathrm{CO}_{2}$ produced during microbial respiration increases acidity and adds to the regional effects of ocean acidification (Ekstrom et al. 2015). In the absence of additional information, we use $25 \%$ as the role of agriculture in driving change on this PB (Fig. 1), this being the proportion of $\mathrm{CO}_{2}$ emissions generated by agriculturally driven land-cover change relative to total $\mathrm{CO}_{2}$ emissions during the industrial age (Ciais et al. 2013).

Local solutions to the global problem of ocean acidification can incorporate changes in agricultural practices. The IUCN Blue Carbon initiative recognizes the ability of coastal vegetation (algae, seagrass, mangroves) to prevent acid water run-off, capture and store carbon, as well as raising the $\mathrm{pH}$ of coastal waters. Seaweed farming and the gradual restoration of mangroves in areas that have been converted to shrimp farms are ways in which agriculture can operate more safely within our PBs (Siikamäki et al. 2013).

\section{STRATOSPHERIC OZONE DEPLETION}

Rockström et al. (2009a) consider the PB for ozone levels to be a $<5 \%$ decrease in column ozone levels for any particular latitude with respect to 1964-1980 values. Ozone depletion to date is dominated by halogens released from historical chlorofluorocarbon emissions, with $\mathrm{N}_{2} \mathrm{O}$ playing a comparatively minor role. However, ozone depletion attributable to $\mathrm{N}_{2} \mathrm{O}$ is projected to grow in importance, as " $\mathrm{N}_{2} \mathrm{O}$ is currently the single most important ozone-depleting emission and is expected to remain the largest throughout the 21st century" (Ravishankara et al. 2009:123).

$\mathrm{N}_{2} \mathrm{O}$ from soils is the main source of anthropogenic $\mathrm{N}_{2} \mathrm{O}$, and is mainly associated with $\mathrm{N}$ fertilizers and manure applied to soils. Increased nitrogen fertilizer use and increased animal manure production are projected to increase agricultural $\mathrm{N}_{2} \mathrm{O}$ emissions by $35-60 \%$ up to 2030 (Smith et al. 2008). Crutzen et al. (2008) calculate an anthropogenic $\mathrm{N}_{2} \mathrm{O}$ source of 5.6-6.5 $\mathrm{Mt} \mathrm{N}_{2} \mathrm{O}-\mathrm{N} \mathrm{yr}^{-1}$ with agriculture contributing 4.3-5.8 $\mathrm{Mt} \mathrm{N}_{2} \mathrm{O}-\mathrm{N} \mathrm{yr}^{-1}$. It then follows that $66-90 \%$ of global anthropogenic $\mathrm{N}_{2} \mathrm{O}$ emissions can be attributed to agricultural activities. Montzka et al. (2011) 
calculate numbers that suggest that $49-83 \%$ of the global anthropogenic $\mathrm{N}_{2} \mathrm{O}$ emissions are from agricultural activities. Given the historical emissions of chlorofluorocarbons, the current influence of agriculture is quite low; we have used a value of 5\% in Figure 1, recognizing that agriculture's share will increase in future.

Numerous options to mitigate anthropogenic $\mathrm{N}_{2} \mathrm{O}$ emissions are currently available, and for agriculture the most effective include more efficient use of fertilizer on cropland (Ravishankara et al. 2009). Limiting future $\mathrm{N}_{2} \mathrm{O}$ emissions would enhance the recovery of the ozone layer from its depleted state. This would also reduce the anthropogenic forcing of the climate system,

\section{ATMOSPHERIC AEROSOL LOADING}

Aerosol particles in the atmosphere are detrimental to human health and are well known to affect climate (Ramanathan et al. 2007). Indeed emissions of the aerosol "black carbon" may be the second most important contributor to global warming after carbon dioxide emissions (Bond et al. 2013). Crop residue burning is known to be a significant global source of atmospheric aerosols (van der Werf et al. 2010) although there is little consensus on the exact figures. Assessment of the literature puts the share of anthropogenic emissions of black and organic carbon at about 3-14\% (Bond et al. 2013).

The PB for atmospheric aerosol loading uses "aerosol optical depth" (AOD) as the control variable. No global boundary has been set, since AOD is so variable over the surface of the Earth. Instead a regional boundary over the Indian subcontinent was set by Steffen et al. (2015) because of its potential influence on the life-giving monsoon. The background AOD over the Indian subcontinent is $\sim 0.15$ (Chin et al. 2014) and the boundary was set at 0.3 (Steffen et al. 2015). The AOD is, however, strongly seasonal and spatially inhomogeneous, with values over the Indo-Gangetic plain routinely near 1.0 in the dry season.

AOD is influenced by the full atmospheric column of aerosol, but because nearly all emissions originate at the surface it is also correlated with small surface particulate matter (PM). The annual average population weighted PM exposure is $\sim 38 \%$ from black and organic carbon and $\sim 11 \%$ from ammonia (Shindell 2015), indicating that emissions related to agricultural burning contributes about $3 \%$ and those related to fertilizer production and usage about $11 \%$ of global PM, though agriculture-related emissions are the dominant source of PM in some densely populated areas (Bauer et al. 2016). Because the Global Burden of Disease estimates that about 3.2 million premature deaths are attributable to small PM each year (Lim et al. 2012), this suggests that agriculture's contribution to atmospheric aerosol loading may be responsible for $\sim 450,000-660,000$ premature deaths annually based on this analysis and another study (Lelieveld et al. 2015). In conclusion, agriculture contributes substantially to atmospheric aerosol loading and this PB is probably regularly (seasonally) transgressed in polluted areas and has extremely damaging effects on human health. Banning the open burning of agricultural wastes and using fertilizer more efficiently would lead to substantial benefits.

\section{INTRODUCTION OF NOVEL ENTITIES}

This PB was widened by Steffen et al. (2015) from the original "chemical pollution" described by Rockström et al. (2009a) to include other new types of engineered materials or organisms, e.g., transgenic organisms, though much of the discussion still relates to chemicals. Steffen et al. (2015:1259855-8) state that, "there is not yet an aggregate, global-level analysis of chemical pollution on which to base a control variable or a [planetary] boundary value." This is because the myriad of chemicals being produced and mobilized during the Anthropocene defy any straightforward attempt at quantification (Conway and Pretty 2013). Nevertheless the impact of anthropogenic chemicals on ecosystem functioning has been described for many case studies (Milton et al. 2011, Pease 2011) and agriculture is strongly implicated. Many pesticides, for example, are used widely in both agri- and aquaculture and are typically highly biologically active. In a review of the role of the global impact of agricultural insecticides on freshwaters, Stehle and Schulz (2015) report that the concentrations of $50 \%$ of the insecticides detected exceeded regulatory thresholds.

It is not clear that broadening this $\mathrm{PB}$ to include genetically modified organisms (GMOs) is appropriate. There are environmental (and other) concerns related to using GMOs in agriculture, though the field is marked by controversy (Trumbo and Powell 2016). Unproven concerns include those related to supposed allergernicity, food unsafety, transgene flow threatening biodiversity integrity, and spread of undesirable traits to weeds. There are also concerns about intellectual property rights (IPRs) on seeds, though IPRs are not associated to the PB concept. Abberton et al. (2016) give a summary on how to use and adapt genomic tools to speed the breeding of both major and minor crops with the aim of boosting production, diversifying food supply, and enhancing adaptation to, or mitigating the effects of climate change. A worldwide meta-analysis of transgenic maize and soybean indicates that they yield more than their conventional counterparts while reducing production costs and increasing gross margins (Areal et al. 2013). Research also shows that transgenic crops reduced chemical pesticide use by $37 \%$ while increasing both yields by $22 \%$ and farmer profits by $68 \%$ (Klümper and Qaim 2014). A recent review suggests that the transgenic cultivar pipeline appears to be very promising for developing more nutritious and inputefficient crops for the world's farming systems under a changing climate (Ortiz et al. 2014). Engineered organisms may assist society in transforming agriculture in a positive direction, e.g., through reducing the use of other "novel entities" such as chemicals in pesticides. This is surely a very complex planetary boundary requiring thorough thinking for properly defining its components.

\section{CONCLUSIONS}

While adapting to climate change and reducing the impact of agriculture, humanity will have to address the fact that at least a billion people do not have access to sufficient calories (FAO 2014), and more than two billion people lack sufficient nutrients (WHO and FAO 2014), while, paradoxically, at the same time over two billion people consume too many calories ( $\mathrm{Ng}$ et al. 2014). This under- and overconsumption has led to a growing "triple burden" of malnutrition (IFPRI 2015) and addressing this is a major societal challenge. Against this background is the fact that global human population is anticipated to reach $\sim 9$ billion by 2050 , and food consumption patterns are changing rapidly as average wealth increases leading to consumption of more food overall, and particularly more meat (Kearney 2010). Of particular concern regarding the PBs is the dietary change leading to overconsumption because this has a disproportionate impact per person. There is 
therefore an urgent need to manage, rather than meet, demand (Ingram 2017).

Of the nine PBs, five are in the high risk or increasing risk zones, with agriculture the major driver of four of them and a significant driver of the remaining one (Fig. 1). It is also a significant driver of many of the PBs still in the safe zone. There are numerous possible intervention points to reduce the impact of agriculture on PBs (Sayer and Cassman 2013). However, nothing less than a radically transformed system will be required, with numerous changes made to all aspects of production, with more attention to landscape-level management, and with changes made to all aspects of the broader food system (Beddington et al. 2012, Ingram and Porter 2015). This is because all food system activities, from agriculture, through processing, logistics and retail, to consuming, affect PBs to some extent (Ingram 2011), and thereby offer a wide range of mitigation possibilities.

Although managing demand is fundamental to mitigate impacts on PBs, there is no doubt that more land will need to be brought under cultivation, but this will need to be carefully selected and managed to reduce impact on PBs. Improved land-management strategies, aimed at environmental, social, and economic benefit should also be implemented. The following examples are provided by Foley et al. (2005): (i) increasing agricultural production per unit land area, per unit fertilizer input, and per unit water consumed; (ii) maintaining and increasing soil organic matter in croplands, which is a key to water holding capacity, nutrient availability, and carbon sequestration; (iii) employing agroforestry practices that provide food and fiber yet maintain habitats for threatened species; and (iv) maintaining local biodiversity and associated ecosystem services such as pollination and pest control. Landscape level solutions will need to be sought, including, e.g., use of coastal vegetation to prevent acid water run-off, restoration of mangroves, and establishing and maintaining riparian buffers. Options around using less $\mathrm{P}$ could include increasing the use of recycled $\mathrm{P}$ from manure, human excreta, and food residues. Reducing food waste, in storage or in after-market waste, so that less has to be produced is an urgent need. Reduced meat and dairy consumption is likely to be crucial. High tech solutions may involve breeding cattle for lower methane emissions; and modifying crop quality to improve the efficiency of postfarm gate food chain activities, such as food processing and storage.

In summary a more balanced consumption-production approach is needed, overall, in which agriculture plays a key part of a complex, and highly integrative overall food system. A holistic approach should also create opportunities that may help to smooth the transition from business-as-usual to a more sustainable food system (Ingram et al. 2016). The "improvement" of agriculture and the overall food system is rightly perceived as being a significant step toward the sustainable development of our planet.

Responses to this article can be read online at: http://www.ecologyandsociety.org/issues/responses. $\mathrm{php} / 9595$

\section{Acknowledgments:}

This work was implemented as part of the CGIAR Research Program on Climate Change, Agriculture and Food Security (CCAFS), which is carried out with support from CGIAR Fund Donors and through bilateral funding agreements. For details please visit https:/lccafs.cgiar.org/donors\#. WcVFTcZryUk. The views expressed in this document cannot be taken to reflect the official opinions of these organizations.

\section{LITERATURE CITED}

Abberton, M., J. Batley, A. Bentley, J. Bryant, H. Cai, J. Cockram, A. Costa de Oliveira, L. J. Cseke, H. Dempewolf, C. De Pace, D. Edwards, P. Gepts, A. Greenland, A. E. Hall, R. Henry, K. Hori, G. T. Howe, S. Hughes, M. Humphreys, D. Lightfoot, A. Marshall, S. Mayes, H. T. Nguyen, F. C. Ogbonnaya, R. Ortiz, A. H. Paterson, R. Tuberosa, B. Valliyodan, R. Varshney, and M. Yano. 2016. Global agricultural intensification during climate change: a role for genomics. Plant Biotechnology Journal 14:1095-1098. http://dx.doi.org/10.1111/pbi.12467

Areal, F. J., L. Riesgo, and E. Rodríguez-Cerezo. 2013. Economic and agronomic impact of commercialized GM crops: a metaanalysis. Journal of Agricultural Sciences 151:7-33. http://dx.doi. org/10.1017/S0021859612000111

Bauer, S. E., K. Tsigaridis, and R. Miller. 2016. Significant atmospheric aerosol pollution caused by world food cultivation. Geophysical Research Letters 43:5394-5400. http://dx.doi. org/10.1002/2016GL068354

Beddington, J. R., M. Asaduzzaman, M. E. Clark, A. Fernández Bremauntz, M. D. Guillou, D. J. B. Howlett, M. M. Jahn, E. Lin, T. Mamo, C. Negra, et al. 2012. What next for agriculture after Durban. Science 335(6066):289-290. http://dx.doi.org/10.1126/ science. 1217941

Blaser, J., and C. Robledo. 2007. Initial analysis on the mitigation potential in the forestry sector. United Nations Framework Convention on Climate Change, New York, New York, USA. [online] URL: https://unfccc.int/files/cooperation_and_support/ financial mechanism/application/pdf/blaser.pdf

Bodirsky, B. L., A. Popp, I. Weindl, J. P. Dietrich, S. Rolinski, L. Scheiffele, C. Schmitz, and H. Lotze-Campen. 2012. $\mathrm{N}_{2} \mathrm{O}$ emissions from the global agricultural nitrogen cycle - current state and future scenarios. Biogeosciences 9(10):4169-4197. http:// dx.doi.org/10.5194/bg-9-4169-2012

Bond, T. C., S. J. Doherty, D. W. Fahey, P. M. Forster, T. Berntsen, B. J. DeAngelo, M. G. Flanner, S. Ghan, B. Kärcher, D. Koch, S. Kinne, Y. Kondo, P. K. Quinn, M. C. Sarofim, M. G. Schultz, M. Schulz, C. Venkataraman, H. Zhang, S. Zhang, N. Bellouin, S. K. Guttikunda, P. K. Hopke, M. Z. Jacobson, J. W. Kaiser, Z. Klimont, U. Lohmann, J. P. Schwarz, D. Shindell, T. Storelvmo, S. G. Warren, and C. S. Zender. 2013. Bounding the role of black carbon in the climate system: a scientific assessment. Journal of Geophysical Research: Atmospheres 118(11):5380-5552. http://dx. doi.org/10.1002/jgrd.50171

Bouwman, A. F., A. H. W. Beusen, and G. Billen. 2009. Human alteration of the global nitrogen and phosphorus soil balances 
for the period 1970-2050. Global Biogeochemical Cycles 23(4): GB0A04. http://dx.doi.org/10.1029/2009GB003576

Boysen, L. R.,, W. Lucht, D. Gerten, V. Heck, T. M. Lenton, and H. J. Schellnhuber. 2017. The limits to global-warming mitigation by terrestrial carbon removal. Earth's Future 5:463-474. http://dx. doi.org/10.1002/2016EF000469

Canfield, D. E., A. N. Glazer, and P. G. Falkowski. 2010. The evolution and future of Earth's nitrogen cycle. Science 330 (6001):192-196. http://dx.doi.org/10.1126/science.1186120

Carpenter, S. R., and E. M. Bennett. 2011. Reconsideration of the planetary boundary for phosphorus. Environmental Research Letters 6(1):014009. http://dx.doi.org/10.1088/1748-9326/6/1/014009

Chin, M., T. Diehl, Q. Tan, J. M. Prospero, R. A. Kahn, L. A. Remer, H. Yu, A. M. Sayer, H. Bian, I. V. Geogdzhayev, et al. 2014. Multi-decadal aerosol variations from 1980 to 2009: a perspective from observations and a global model. Atmospheric Chemistry and Physics 14(7):3657-3690. http://dx.doi.org/10.5194/ acp-14-3657-2014

Ciais, P., C. Sabine, G. Bala, L. Bopp, V. Brovkin, J. Canadell, A. Chhabra, R. DeFries, J. Galloway, M. Heimann, C. Jones, C. Le Quéré, R. B. Myneni, S. Piao, and P. Thornton. 2013. Carbon and other biogeochemical cycles. Pages 465-570 in T. F. Stocker, D. Qin, G.-K. Plattner, M. Tignor, S. K. Allen, J. Boschung, A. Nauels, Y. Xia, V. Bex, and P. M. Midgley, editors. Climate change 2013: the physical science basis. Contribution of Working Group I to the Fifth Assessment report of the Intergovernmental Panel on Climate Change Cambridge University Press, Cambridge, UK.

Conway, G. R., and J. N. Pretty. 2013. Unwelcome harvest: agriculture and pollution. Earthscan, London, UK.

Cordell, D., and S. White. 2013. Sustainable phosphorus measures: strategies and technologies for achieving phosphorus security. Agronomy 3(1):86-116. http://dx.doi.org/10.3390/ agronomy 3010086

Costello, M. J., S. Wilson, and B. Houlding. 2013. More taxonomists describing significantly fewer species per unit effort may indicate that most species have been discovered. Systematic Biology 62(4):616-624. http://dx.doi.org/10.1093/sysbio/syt024

Crutzen, P. J., A. R. Mosier, K. A. Smith, and W. Winiwarter. 2008. $\mathrm{N}_{2} \mathrm{O}$ release from agro-biofuel production negates global warming reduction by replacing fossil fuels. Atmospheric Chemistry and Physics 8:389-395. http://dx.doi.org/10.5194/ acp-8-389-2008

Crutzen, P. J., and E. F. Stoermer. 2000. Global change newsletter. Anthropocene 41:17-18.

Destouni, G., F. Jaramillo, and C. Prieto. 2013. Hydroclimatic shifts driven by human water use for food and energy production. Nature Climate Change 3(3):213-217. http://dx.doi.org/10.1038/ $\underline{\text { nclimate } 1719}$

de Vries, W., J. Kros, C. P. Kroeze, and S. P. Seitzinger. 2013. Assessing planetary and regional nitrogen boundaries related to food security and adverse environmental impacts. Current Opinion in Environmental Sustainability 5(3-4):392-402. http://dx. doi.org/10.1016/j.cosust.2013.07.004
Diaz, R. J., and R. Rosenberg. 2008. Spreading dead zones and consequences for marine ecosystems. Science 321(5891):926-929. http://dx.doi.org/10.1126/science.1156401

Ekstrom, J. A., L. Suatoni, S. R. Cooley, L. H. Pendleton, G. G. Waldbusser, J. E. Cinner, J. Ritter, C. Langdon, R. van Hooidonk, D. Gledhill, et al. 2015. Vulnerability and adaptation of US shellfisheries to ocean acidification. Nature Climate Change 5 (3):207-214. http://dx.doi.org/10.1038/nclimate2508

Elser, J., and E. Bennett. 2011. Phosphorus cycle: a broken biogeochemical cycle. Nature 478(7367):29-31. http://dx.doi. org/10.1038/478029a

Fixen, P. E., and F. B. West. 2002. Nitrogen fertilizers: meeting contemporary challenges. AMBIO: A Journal of the Human Environment 31(2):169-176. http://dx.doi.org/10.1579/0044-7447-31.2.169

Foley, J. A., R. DeFries, G. P. Asner, C. Barford, G. Bonan, S. R. Carpenter, F. S. Chapin, M. T. Coe, G. C. Daily, H. K. Gibbs, et al. 2005. Global consequences of land use. Science 309 (5734):570-574. http://dx.doi.org/10.1126/science.1111772

Food and Agriculture Organization of the United Nations (FAO). 2014. The state of food insecurity in the world. Strengthening the enabling environment for food security and nutrition. FAO, Rome, Italy.

Galloway, J. N., A. R. Townsend, J. W. Erisman, M. Bekunda, Z. Cai, J. R. Freney, L. A. Martinelli, S. P. Seitzinger, and M. A. Sutton. 2008. Transformation of the nitrogen cycle: recent trends, questions, and potential solutions. Science 320(5878):889-892. http://dx.doi.org/10.1126/science.1136674

Gattuso, J. P., A. Magnan, R. Billé, W. W. L. Cheung, E. L. Howes, F. Joos, D. Allemand, L. Bopp, S. R. Cooley, C. M. Eakin, et al. 2015. Contrasting futures for ocean and society from different anthropogenic $\mathrm{CO}_{2}$ emissions scenarios. Science 349(6243): aac4722. http://dx.doi.org/10.1126/science.aac4722

Gerten, D., H. Hoff, J. Rockström, J. Jägermeyr, M. Kummu, and A. V. Pastor. 2013. Towards a revised planetary boundary for consumptive freshwater use: role of environmental flow requirements. Current Opinion in Environmental Sustainability 5 (6):551-558. http://dx.doi.org/10.1016/j.cosust.2013.11.001

Gerten, D., J. Rockström, J. Heinke, W. Steffen, K. Richardson, and S. Cornell. 2015. Response to comment on "Planetary boundaries: guiding human development on a changing planet." Science 348(6240):1217. http://dx.doi.org/10.1126/science.aab0031

Gibbs, H. K., A. S. Ruesch, F. Achard, M. K. Clayton, P. Holmgren, N. Ramankutty, and J. A. Foley. 2010. Tropical forests were the primary sources of new agricultural land in the 1980s and 1990s. Proceedings of the National Academy of Sciences 107 (38):16732-16737. http://dx.doi.org/10.1073/pnas.0910275107

Handoh, I. C., and T. M. Lenton. 2003. Periodic mid-cretaceous oceanic anoxic events linked by oscillations of the phosphorus and oxygen biogeochemical cycles. Global Biogeochemical Cycles 17(4):1092. http://dx.doi.org/10.1029/2003GB002039

Hönisch, B., A. Ridgwell, D. N. Schmidt, E. Thomas, S. J. Gibbs, A. Sluijs, R. Zeebe, L. Kump, R. C. Martindale, S. E. Greene, et al. 2012. The geological record of ocean acidification. Science 335 (6072):1058-1063. http://dx.doi.org/10.1126/science.1208277 
Hosonuma, N., M. Herold, V. De Sy, R. S. De Fries, M. Brockhaus, L. Verchot, A. Angelsen, and E. Romijn. 2012. An assessment of deforestation and forest degradation drivers in developing countries. Environmental Research Letters 7(4). http:// dx.doi.org/10.1088/1748-9326/7/4/044009

Howarth, R., D. Swaney, G. Billen, J. Garnier, B. Hong, C. Humborg, P. Johnes, C.-M. Mörth, and R. Marino. 2011. Nitrogen fluxes from the landscape are controlled by net anthropogenic nitrogen inputs and by climate. Frontiers in Ecology and the Environment 10(1):37-43. http://dx.doi. org/10.1890/100178

Ingram, J. S. I. 2011. A food systems approach to researching food security and its interactions with global environmental change. Food Security 3:417-431 http://dx.doi.org/10.1007/s12571-011-0149-9

Ingram, J. S. I. 2017. Look beyond production. Nature 544(S17). http://dx.doi.org/10.1038/544S17a

Ingram, J. S. I., R. Dyball, H. Howden, S. Vermeulen, T. Garnett, B. Redlingshöfer, S. Guilbert, and J. R. Porter. 2016. Feeding future generations with limited resources. Solutions MayJune:63-71.

Ingram, J. S. I., and J. R. Porter. 2015. Plant science and the food security agenda. Nature Plants 1(11):15173. http://dx.doi. org/10.1038/nplants.2015.173

International Food Policy Research Institute (IFPRI). 2015. Actions and accountability to advance nutrition and sustainable development. Global Nutritions Report. IFPRI, Washington D. C., USA.

Jaramillo, F., and G. Destouni. 2015a. Comment on "Planetary boundaries: guiding human development on a changing planet." Science 348(6240):1217. http://dx.doi.org/10.1126/science.aaa9629

Jaramillo, F., and G. Destouni. 2015b. Local flow regulation and irrigation raise global human water consumption and footprint. Science 350(6265):1248-1251. http://dx.doi.org/10.1126/science. $\underline{\operatorname{aad} 1010}$

Kearney, J. 2010. Food consumption trends and drivers. Philosophical Transactions of the Royal Society of London B: Biological Sciences 365(1554):2793-2807. http://dx.doi.org/10.1098/ $\underline{\text { rstb.2010.0149 }}$

Kissinger, G., M. Herold, and V. De Sy. 2012. Drivers of deforestation and forest degradation: a synthesis report for REDD+ policymakers. Lexeme Consulting, Vancouver, British Columbia, Canada.

Klümper, W., and M. Qaim. 2014. A meta-analysis of the impacts of genetically modified crops. PLOS ONE 9(11):e111629. http:// dx.doi.org/10.1371/journal.pone.0111629

Laurance, W. F., S. Sloan, L. Weng, and J. A. Sayer. 2015. Estimating the environmental costs of Africa's massive development corridors. Current Biology 25(24):3202-3208. http:// dx.doi.org/10.1016/j.cub.2015.10.046

Lelieveld, J., J. S. Evans, M. Fnais, D. Giannadaki, and A. Pozzer. 2015. The contribution of outdoor air pollution sources to premature mortality on a global scale. Nature 525(7569):367-371. http://dx.doi.org/10.1038/nature15371
Lim, S., T. Vos, A. Flaxman, G. Danaei, K. Shibuya, H. AdairRohani, M. A. Al Mazroa, M. Amann, H. R. Anderson, K. G. Andrews, et al. 2012. A comparative risk assessment of burden of disease and injury attributable to 67 risk factors and risk factor clusters in 21 regions, 1990-2010: a systematic analysis for the Global Burden of Disease Study 2010. Lancet 380:2224-2260. http://dx.doi.org/10.1016/S0140-6736(12)61766-8

Liu, J., L. You, M. Amini, M. Obersteiner, M. Herrero, A. J. B. Zehnder, and H. Yang. 2010. A high-resolution assessment on global nitrogen flows in cropland. Proceedings of the National Academy of Sciences 107(17):8035-8040. http://dx.doi.org/10.1073/ pnas.0913658107

Mahowald, N. M., R. Scanza, J. Brahney, C. L. Goodale, P. G. Hess, J. K. Moore, and J. Neff. 2017. Aerosol deposition impacts on land and ocean carbon cycles. Current Climate Change Reports 3(1):16-31. http://dx.doi.org/10.1007/s40641-017-0056-Z

Milton, M., K. Ambrose, C. Abraham, N. Charles, and K. Kiriamiti. 2011. Dichlorodiphenyl trichloroethane (DDT) and its observed effects on body functions in vertebrates. East African Journal of Public Health 8(4):271-274.

Molden, D. 2009. Planetary boundaries: the devil is in the detail. Nature Reports Climate Change September:116-117. http://dx. doi.org/10.1038/climate.2009.97

Montzka, S. A., E. J. Dlugokencky, and J. H. Butler. 2011. Non$\mathrm{CO}_{2}$ greenhouse gases and climate change. Nature 476 (7358):43-50. http://dx.doi.org/10.1038/nature10322

Newbold, T., L. N. Hudson, A. P. Arnell, S. Contu, A. De Palma, S. Ferrier, S. L. Hill, A. J. Hoskins, I. Lysenko, H. R. Phillips, and V. J. Burton et al. 2016. Has land use pushed terrestrial biodiversity beyond the planetary boundary? A global assessment. Science 353(6296):288-291. http://dx.doi.org/10.1126/ $\underline{\text { science.aaf2201 }}$

Ng, M., T. Fleming, M. Robinson, B. Thomson, N. Graetz, C. Margono, E. C. Mullany, S. Biryukov, C. Abbafati, S. F. Abera, et al. 2014. Global, regional, and national prevalence of overweight and obesity in children and adults during 1980-2013: a systematic analysis for the global burden of disease study 2013. Lancet 384(9945):766-781. http://dx.doi.org/10.1016/S0140-6736 (14) $60460-8$

Ortiz, R., A. Jarvis, P. Fox, P. K. Aggarwal, and B. M. Campbell. 2014. Plant genetic engineering, climate change and food security. CCAFS Working Paper 72. CGIAR Research Program on Climate Change, Agriculture and Food Security (CCAFS), Copenhagen, Denmark.

Pease, C. M. 2011. A tale of pesticides then and now. Environmental Forum 28:18. [online] URL:http://www-assets. vermontlaw.edu/Assets/directories/FacultyDocuments/ PeaseForumMarApr2011.pdf

Ramanathan, V., M. V. Ramana, G. Roberts, D. Kim, C. Corrigan, C. Chung, and D. Winker. 2007. Warming trends in Asia amplified by brown cloud solar absorption. Nature 448(7153):575-578. http://dx.doi.org/10.1038/nature06019

Ramankutty, N., A. T. Evan, C. Monfreda, and J. A. Foley. 2008. Farming the planet: 1. Geographic distribution of global 
agricultural lands in the year 2000. Global Biogeochemical Cycles 22(1):GB1003. http://dx.doi.org/10.1029/2007GB002952

Ravishankara, A. R., J. S. Daniel, and R. W. Portmann. 2009. Nitrous oxide $\left(\mathrm{N}_{2} \mathrm{O}\right)$ : the dominant ozone-depleting substance emitted in the 21st century. Science 326(5949):123-125. http://dx. doi.org/10.1126/science.1176985

Richards, M., T. Bruun, B. M. Campbell, S. Huyer, V. Kuntze, L. E. Gregersen, S. T. N. Madsen, M. B. Oldvig, and I. Vasileiou. 2015. How countries plan to address agricultural adaptation and mitigation: an analysis of intended nationally determined contributions. CGIAR Research Program on Climate Change, Agriculture and Food Security (CCAFS), Copenhagen, Denmark.

Robertson, G. P., and P. M. Vitousek. 2009. Nitrogen in agriculture: balancing the cost of an essential resource. Annual Review of Environment and Resources 34(1):97-125. http://dx.doi. org/10.1146/annurev.environ.032108.105046

Rockström, J., W. Steffen, K. Noone, Å. Persson, F. S. Chapin, E. F. Lambin, T. M. Lenton, M. Scheffer, C. Folke, H. J. Schellnhuber, B. Nykvist, C. A. de Wit, et al. 2009a. A safe operating space for humanity. Nature 461(7263):472-475. http:// dx.doi.org/10.1038/461472a

Rockström, J., W. Steffen, K. Noone, Å. Persson, F. S. Chapin, III, E. Lambin, T. M. Lenton, M. Scheffer, C. Folke, H. Schellnhuber, B. Nykvist, C. A. De Wit, T. Hughes, S. van der Leeuw, H. Rodhe, S. Sörlin, P. K. Snyder, R. Costanza, U. Svedin, M. Falkenmark, L. Karlberg, R. W. Corell, V. J. Fabry, J. Hansen, B. Walker, D. Liverman, K. Richardson, P. Crutzen, and J. Foley. 2009b. Planetary boundaries: exploring the safe operating space for humanity. Ecology and Society 14(2):32. http://dx.doi. org/10.5751/ES-03180-140232

Rodolfo-Metalpa, R., F. Houlbrèque, E. Tambutté, F. Boisson, C. Baggini, F. P. Patti, R. Jeffree, M. Fine, A. Foggo, J. P. Gattuso, and J. M. Hall-Spencer. 2011. Coral and mollusc resistance to ocean acidification adversely affected by warming. Nature Climate Change 1:308-312. http://dx.doi.org/10.1038/nclimate1200

Rosegrant, M. W., C. Ringler, and T. Zhu. 2009. Water for agriculture: maintaining food security under growing scarcity. Annual Review of Environment and Resources 34(1):205-222. http://dx.doi.org/10.1146/annurev.environ.030308.090351

Sayer, J., and K. G. Cassman. 2013. Agricultural innovation to protect the environment. Proceedings of the National Academy of Sciences 110(21):8345-8348. http://dx.doi.org/10.1073/pnas. 1208054110

Shiklomanov, I. A., and J. C. Rodda. 2003. World water resources at the beginning of the twenty-first century. Cambridge University Press, Cambridge, UK.

Shindell, D. T. 2015. The social cost of atmospheric release. Climatic Change 130:313-326. http://dx.doi.org/10.1007/ s10584-015-1343-0

Shindell, D. T. 2016. Crop yield changes induced by emissions of individual climate-altering pollutants. Earth's Future 4 (8):373-380. http://dx.doi.org/10.1002/2016EF000377

Siebert, S., and P. Döll. 2010. Quantifying blue and green virtual water contents in global crop production as well as potential production losses without irrigation. Journal of Hydrology 384 (3-4):198-217. http://dx.doi.org/10.1016/j.jhydrol.2009.07.031

Siikamäki, J., J. N. Sanchirico, S. Jardine, D. McLaughlin, and D. Morris. 2013. Blue carbon: coastal ecosystems, their carbon storage, and potential for reducing emissions. Environment: Science and Policy for Sustainable Development 55(6):14-29. http://dx.doi.org/10.1080/00139157.2013.843981

Sloan, S., and J. A. Sayer. 2015. Forest resources assessment of 2015 shows positive global trends but forest loss and degradation persist in poor tropical countries. Forest Ecology and Management 352:134-145. http://dx.doi.org/10.1016/j.foreco.2015.06.013

Smil, V. 2000. Phosphorus in the environment: natural flows and human interferences. Annual Review of Energy and the Environment 25(1):53-88. http://dx.doi.org/10.1146/annurev. energy.25.1.53

Smith, P., M. Bustamante, H. Ahammad, H. Clark, H. Dong, E. A. Elsiddig, H. Haberl, R. Harper, J. House, M. Jafari, et al. 2014. Agriculture, forestry and other land use (AFOLU). Pages 811-922 in Edenhofer, O., R. Pichs-Madruga, Y. Sokona, E. Farahani, S. Kadner, K. Seyboth, A. Adler, I. Baum, S. Brunner, P. Eickemeier, B. Kriemann, J. Savolainen, S. Schlömer, C. von Stechow, T. Zwickel, and J. C. Minx, editors. Climate change 2014: mitigation of climate change. Contribution of Working Group III to the Fifth Assessment Report of the Intergovernmental Panel on Climate Change. Cambridge University Press, Cambridge, UK.

Smith, P., S. J. Davis, F. Creutzig, S. Fuss, J. Minx, B. Gabrielle, E. Kato, R. B. Jackson, A. Cowie, E. Kriegler, et al. 2016. Biophysical and economic limits to negative $\mathrm{CO}_{2}$ emissions. Nature Climate Change 6(1):42-50. http://dx.doi.org/10.1038/ nclimate 2870

Smith, P., D. Martino, Z. Cai, D. Gwary, H. Janzen, P. Kumar, B. McCarl, S. Ogle, F. O'Mara, C. Rice, et al. 2008. Greenhouse gas mitigation in agriculture. Philosophical Transactions of the Royal Society of London B: Biological Sciences 363(1492):789-813. http://dx.doi.org/10.1098/rstb.2007.2184

Steffen, W., K. Richardson, J. Rockström, S. E. Cornell, I. Fetzer, E. M. Bennett, R. Biggs, S. R. Carpenter, W. de Vries, C. A. de Wit, C. Folke, et al. 2015. Planetary boundaries: guiding human development on a changing planet. Science 347(6223):1259855. http://dx.doi.org/10.1126/science.1259855

Stehle, S., and R. Schulz. 2015. Agricultural insecticides threaten surface waters at the global scale. Proceedings of the National Academy of Sciences 112(18):5750-5755. http://dx.doi.org/10.1073/ pnas. 1500232112

Sutton, M. A., O. Oenema, J. W. Erisman, A. Leip, H. van Grinsven, and W. Winiwarter. 2011. Too much of a good thing. Nature 472(7342):159-161. http://dx.doi.org/10.1038/472159a

Swaney, D. P., B. Hong, C. Ti, R. W. Howarth, and C. Humborg. 2012. Net anthropogenic nitrogen inputs to watersheds and riverine N export to coastal waters: a brief overview. Current Opinion in Environmental Sustainability 4(2):203-211. http://dx. doi.org/10.1016/j.cosust.2012.03.004

Trumbo, J., and D. Powell. 2016. Why transgenic plants are so controversial. Pages 366-382 in C. N. Stewart Jr, editor. Plant 
biotechnology and genetics: principles, techniques, and applications. John Wiley \& Sons, Hoboken, New Jersey, USA.

U.S. Environmental Protection Agency (EPA). 2011. Global anthropogenic non- $\mathrm{CO}_{2}$ greenhouse gas emissions:1990-2030. Draft report 1. Office of Atmospheric Programs, Washington, D. C., USA.

van der Werf, G. R., J. T. Randerson, L. Giglio, G. J. Collatz, M. $\mathrm{Mu}$, P. S. Kasibhatla, D. C. Morton, R. S. DeFries, Y. Jin, and T. T. van Leeuwen. 2010. Global fire emissions and the contribution of deforestation, savanna, forest, agricultural, and peat fires (1997-2009). Atmospheric Chemistry and Physics 10(23):11707-11735. http://dx.doi.org/10.5194/acp-10-11707-2010

Vermeulen, S. J., B. M. Campbell, and J. S. I. Ingram. 2012. Climate change and food systems. Annual Review of Environment and Resources 37(1):195-222. http://dx.doi.org/10.1146/annurevenviron-020411-130608

Wada, Y., L. P. H. van Beek, C. M. van Kempen, J. W. T. M. Reckman, S. Vasak, and M. F. P. Bierkens. 2010. Global depletion of groundwater resources. Geophysical Research Letters 37(20): L20402. http://dx.doi.org/10.1029/2010GL044571

Wollenberg, E., M. Richards, P. Smith, P. Havlík, M. Obersteiner, F. N. Tubiello, M. Herold, P. Gerber, S. Carter, A. Reisinger, D. van Vuuren, A. Dickie, H. Neufeldt, B. O. Sander, R. Wassmann, R. Sommer, J. E. Amonette, A. Falcucci, M. Herrero, C. Opio, R. Roman-Cuesta, E. Stehfest, H. Westhoek, I. Ortiz-Monasterio, T. Sapkota, M. C. Rufino, P. K. Thornton, L. Verchot, P. C. West, J.-F. Soussana, T. Baedeker, M. Sadler, S. J. Vermeulen, and B. M. Campbell. 2016. Reducing emissions from agriculture to meet the $2{ }^{\circ} \mathrm{C}$ target. Global Change Biology 22(12):3859-3864. http:// dx.doi.org/10.1111/gcb. 13340

World Health Organization and Food and Agriculture Organization (WHO and FAO). 2014. Countries vow to combat malnutrition through firm policies and actions. WHO, Geneva, Switzerland. [online] URL: http://www.who.int/mediacentre/ news/releases/2014/icn2-nutrition/en/

World Water Assessment Programme (WWAP). 2012a. The United Nations world water development report 4: facing the challenges. Volume 3. UNESCO, Paris, France.

World Water Assessment Programme (WWAP). 2012b. The United Nations world water development report 4: knowledge base. Volume 2. UNESCO, Paris, France.

World Water Assessment Programme (WWAP). 2012c. The United Nations world water development report 4: managing water under uncertainty and risk. Volume 1. UNESCO, Paris, France. 